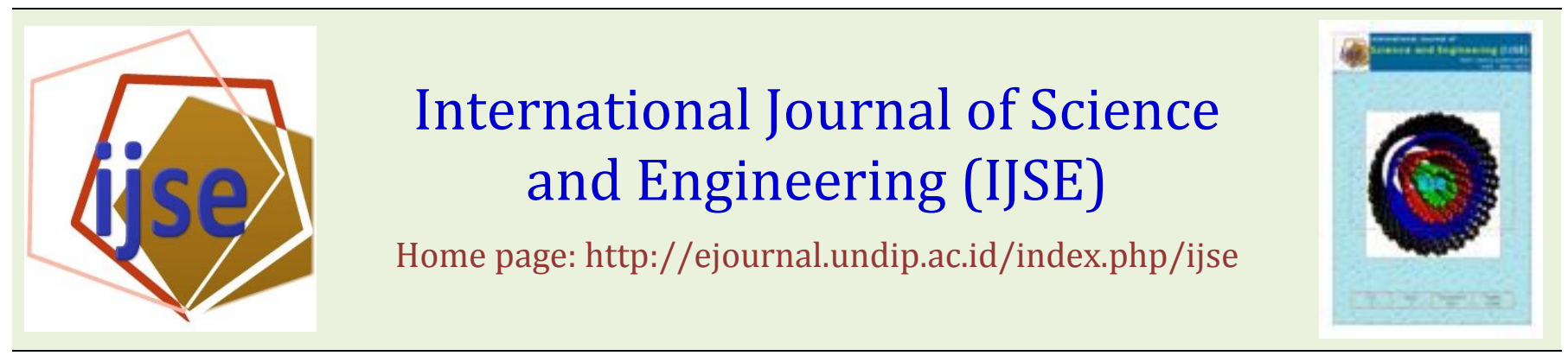

\title{
Utility of Rice Bran Mixed with Fermentation Extract of Vegetable Waste Unconditioned as Probiotics from Vegetable Market
}

\author{
Cahya Setya Utama1, Nyoman Suthama, Bambang Sulistiyanto, Bhakti Etza Setiani \\ Diponegoro University, Semarang, Central Java Indonesia \\ ${ }^{1}$ cahya_su@yahoo.co.id
}

\begin{abstract}
$\overline{\text { Abstract - The aimed of the study was to enhance utilization of Lactobacillus Sp. and Saccharomyces sp. as starter for fermentation of }}$ waste cabbage and green mustard to enhance the utility of rice bran as an ingredient of poultry feed. The first stage of the study was to characterize the extract of fermented wasted vegetable with difference concentration of glucose and different period of time for incubation. Completely randomized design using 3 x 3 factorial with three replications was used for the first stage of the study. The second stage of the study was to evaluate the effectiveness of the extract of fermented wasted vegetable to improve the quality and utility of rice bran. Completely randomized design with four treatments and 4 replications. The third stage of the study was to obtain the value of nitrogen, calcium and phosphorus retention, as well as metabolic energy of rice bran after fermentation in broiler hatching. The third stage analysis was conducted by t-test analysis. The results of the study showed that the microbial characteristics on the extract of fermented wasted vegetable in two days incubation time and 2\% concentration of glucose was able to produce $\mathrm{pH}$ of 3.80 , log of total lactic acid bacteria 7.38 and types of microbes that grow predominantly were Lactobacillus Sp. and Saccharomyces Sp. The effectiveness of the extract fermented wasted vegetable for the fermentation of rice bran were shown in additional concentration of extract wasted vegetable of $40 \%$ with a moisture content of toluene $65.24 \%, 13.36 \%$ ash, $14.93 \%$ protein, $7.61 \%$ crude fat, $12.39 \%$ crude fiber, nitrogen free extract material (NFE) 51.59\% and 0.07\% biomass. The biological value and the availability of fermented rice bran were higher than unfermented rice bran on the broiler chickens after hatching. The values were justified from nitrogen, calcium and phosphorus retention also metabolic energy. The study concluded that the benefits and utility of rice bran could increased by fermentation using $40 \%$ extract of fermented wasted vegetable from vegetable market with $2 \%$ glucose concentration and 2 days incubation time.
\end{abstract}

Key words - extract, wasted, starter bacteria, fermentation, rice bran

Submission: February 26, $2012 \quad$ Corrected : March 30, 2013

Accepted: April 10, 2013

Doi: $10.12777 /$ ijse.4.2.2013.97-102

[How to cite this article: Utama, C.S., Suthama, N., Sulistiyanto, B., Setiani, B.E. (2013). Utility of Rice Bran Mixed with Fermentation Extract of Vegetable Waste Unconditioned as Probiotics from Vegetable Market. International Journal of Science and Engineering, 4(2),97-101. Doi: 10.12777/ijse.4.2.2013.97-102]

\section{INTRODUCTION.}

Rice bran is the rest of the rice mill and used for feeding almost all of the kinds of cattle in Indonesia even for poultry. The proportion use of rice bran for poultry feeding is about 20 to $30 \%$. Nutrient content in rice bran are as follows: $14.5 \%$ crude protein; $48 \%$ nitrogen free extract material (NFE); 7.4\% crude fiber; $7.4 \%$ crude fat; $7.0 \%$ ash; calcium (Ca) 0, 05\%, phosphorus (P) 1.48\%, $10.8 \%$ protein digestible and MP $=70$ (Lubis, 1992). Rice bran have some limitation factors such as low digestibility, easy to be rancid and high level phytic acid. A fermentation process could be an overcome to increase the nutrient content, digestibility and nutrient levels eficiency of rice bran. Reddy and Sathe (2002) stated that reducing the phytic acid content in rice bran can be done by fermentation, heating, soaking and pickling. A natural microbe consist of local ingredients such as extract of fermented wasted vegetable from traditional vegetable market can also be used as a fermentation starter instead of using pure cultures.

The extract of fermented wasted vegetable from vegetable market was made by a fermentation of waste cabbage and green mustard. It contains some species of lactic acid bacteria such as Leuconostoc mesenteroides, Lactobacillus brevis, Lactobacillus plantarum, Pediococcus pentosaceus and Saccharomyces sp that produced the total content of lactic acid bacteria at $2.1 \times 10^{10} \mathrm{CFU} / \mathrm{ml}$ and 
have a potential ability to degrade phytic acid content (Plengvidhya et al., 2007).

Semarang district is very rich and has a great potential for making the extract of fermented wasted vegetable. The potential of the extract of fermented wasted vegetable from cabbage and green mustard greens ranging from 500 $\mathrm{kg}$ up to $800 \mathrm{~kg}$ per day. Meanwhile for the production of vegetable in Semarang District reached 96,906 quintal for cabbage and 78,911 quintals for green mustard, according to the Central Statistics Agency (BPS) Semarang District (2005). Percentage vegetables were sorted from the vegetable market reached $3-5 \%$ by weight of the vegetable with the dominance of $80 \%$ cabbage and $20 \%$ green mustard. Wasted vegetables polluted the market thus it needs to be processed and utilized as a starter lactic acid bacteria for a fermentation process through the production of the extract of fermented wasted vegetable, as well as to overcome one of the environment problems.

The levels of phytic acid could reduced up to $80.4 \%$ by rice bran fermentation process using Lactobacillus for 8 to 72 hours of incubation. On the other side, the levels of phytic acid could reduced up to $20 \%$ by rice bran fermentation process using Saccharomyces Sp. at pH 5.3 (Reddy and Sathe, 2002). The growth of microorganisms in the production of the extract of fermented wasted vegetable was influenced by the availability of the carbon chain in the substrat, particularly glucose. The growing of microorganisms in the fermentation process optimally influenced by the supply of carbon source. The cell size and the number of nucleic acid were affected by the rate of microbial growth. The higher the growth rates will increase the number of cell mass and ribosome per unit of DNA. Purwadaria et al. (2003) stated that the production of biomass $33.3 \times 10^{-1} \mathrm{mg} / \mathrm{ml}$ of SP. 9 isolates using glucose; $15.6 \times 10^{-1} \mathrm{mg} / \mathrm{ml}$ on sucrose and $13.8 \times 10^{-1} \mathrm{mg} / \mathrm{ml}$ for the molasses. Meanwhile when using Saccharomyces cerevisie, the production of biomass reached $4 \times 10^{-1} \mathrm{mg} / \mathrm{ml}$ for glucose; $45.1 \times 10^{-1} \mathrm{mg} / \mathrm{ml}$ on sucrose and $45.2 \times 10^{-1} \mathrm{mg} / \mathrm{ml}$ for the molasses.

Saccharomyces cerevisie can be used for fermentation and animal feed as a probiotic and prebiotic because it contains immunostimulan such as $\beta$-glucan, mannan and oligosaccharides. Saccharomyces cerevisiea has a special characteristic in animal feed because of its ability to produce glutamic acid which can increase the palatability of substrate fermentation media. Tawwab et al. (2008) stated that the given of Saccharomyces cerevisiae in feed could improve the digestibility of protein and fiber such as cellulose and hemicellulose in the digestive tract. The statement was supported by the research of Kumprechtova et al. (2000). They were reported that supplementation with Saccharomyces cerevisiea could improve the productivity of broilers, if there were low proportion of protein content in feed. Supplementation decreased the excretion of nitrogen in the excreta, indicate the better protein utilization. Declining levels of nitrogen give the impact on improving livestock productivity, reduced levels of ammonia and odor from chicken manure thus it could reduce pollution occurs. Saccharomyces cerevisiae are possible to maintain the condition of the gastrointestinal tract. They were survived on the surface of cells of the small intestine (Brugier and Patte 1975). Rose (1987) stated that Saccharomyces cerevisiae was the ideal starter culture for yeast production. They were able to change microbes in the gut, if the $\mathrm{pH}$ was suitable. According to Leeson and Summers (1996), the presence of Saccharomyces cerevisiae was provided the water supply to deliver oxygen, thereby increasing beneficial microbial growth in an aerobic condition. Edo et al. (1999) reported that Saccharomyces cerevisieae can serve as a prebiotic because it can suppress the growth of Enterobacteriaceae. Specific interaction between Saccharomyces cerevisiae and pathogenic bacteria such as Escherichia coli and Salmonella illustrates that Saccaromyces binding the enterotoxigenic of enterobacteria through the mannosespecific reactions on the intestine surface.

The aim of the study was to enhance the used of Lactobacillus sp. and Saccharomyces sp. as a fermentation starter from waste cabbage and green mustard to enhance the utility of rice bran as poultry feed. The combination of the glucose addition and the longer period of incubation probably could change the type and the number of microbes that exist in the liquid of extract of the fermented waste vegetable from market being the hypothetical of the first stage of the study. The Level concentration of using liquid starter of fermented extract wasted vegetable from market probably could altered the nutritional quality and microbiological conditions of rice bran were become the second hypothesis. The hypothesis of the last stages was about the increasing of the utility of fermented rice bran in chickens after hatching due to the addition of liquid extract fermented waste vegetable from market were conditioned by glucose.

\section{RESEARCH METHODS}

The study was consisted of 3 (three) stages of the research, as followed: stages for developing microorganisms in the liquid extract of fermented waste vegetable from market; determination for the capabilities of the liquid fermentation from extract waste vegetable as a starter in fermented rice bran then the evaluation stages for the application of starter solution phase extract vegetable market waste fermentation of metabolic energy, nitrogen retention, retention of calcium and phosphorus retention in chickens aged 10 days.

The material used in this study were waste vegetable from market such as cabbage and green mustard, salt, molasses, liquid extract fermented waste vegetable, $83 \%$ of glucose, distilled water, rice bran, rice bran fermentation, $\mathrm{HCl}$ and 150 chickens with the specifics characteristics such as 10 days old, CP 707 strain and having weights average of $130 \mathrm{~g}+3.49 \mathrm{~g}$. The tools used in this study were the stove, steamer rice, knives, silo (from a plastic bucket), plastic bags, rubber, microbial identification equipment (OSE, autoclave, petri dish, ignition Bunsen, de Man Rogousa and Sharpe media (MRS), saberoute glucose agar (SGA), nutrient agar (NA), fermentation equipment, proximate analysis equipment, spectrometry, microscopy, battery enclosure, digital scales 
brand OHAUS $200 \mathrm{~g}$ capacity with $0.1 \mathrm{~g}$ sensitivity, force feeding utensils and trays.

At the first stages of the study, cabbage and green mustard which obtained from waste vegetable market were chopped. After then added $8 \%$ salt and $6.7 \%$ molasses from the weight of fresh cabbage and green mustard, then mixed thoroughly and ripening for 6 days. Liquid fermented result was taken, after then was added with various level of glucose concentration $(2 \%, 4 \%$ and $6 \%$ ) and incubated for 2, 4 and 6 days. The parameters measured were $\mathrm{pH}$, type of fungi, total bacteria and lactic acid bacteria gram positive/negative with the method according to Atlas (2005).

Completely randomized design with 3 by 3 factorial and three replications was used for the experimental design. The aim of the second stages of the study was to determine the effectiveness of liquid extract of fermented waste vegetable from market as a starter for the fermentation of rice bran in an effort to improve the quality and utility of rice bran as an ingredient of poultry feed.

The research began with steaming rice bran for 30 minutes after the water boils and it was repeated for 3 times in order to eliminate the bacteria for the first steaming, eliminate bacterial spores, molds and yeasts for the second steaming and sterilize rice bran for the third.

The nutritional quality in purpose to determine were followed the water content of toluene, the levels of crude protein, crude fat, crude fiber, ash, nitrogen free extract material (NFE) and biomass. The design used was completely randomized design with 4 treatments $(0 \%$, $20 \%, 40 \%$ and $60 \%$ concentration level of the extract fermented waste vegetable from market waste) and 4 replicates, with the incubation time for 2 days, the proximate analysis using AOAC method and biomass (Hadisuwarno, 1990).

The aim of the third stages of the study was to examine the utility of rice bran fermentation in chickens aged 10 days post-hatching. The experiments were conducted by comparing non-fermented and fermented rice bran then tested on post-hatching chickens with force feeding method (Sulistiyanto, 1998). The parameters measured were retention of $\mathrm{N}, \mathrm{Ca}, \mathrm{P}$ and metabolic energy.

The data were processed by analysis of variant using SAS 98 programe for the 1st and 2nd stages of the study while the 3rd stages of the study using SPSS 10 t-test analysis. If there was any significant effect $(p<0.05)$ continued by Duncan's test area specifically for the first and the second stages of the study (Steel and Torrie, 1993).

\section{RESULTS AND DISCUSSION.}

\section{The Characteristics of Liquids Extract Fermented Waste Vegetables from Market.}

The result of variety analysis on microbial starter growth for fermented rice bran using extract solution waste vegetable market with level fermentation of glucose $2 \%, 4 \%$ and $6 \%$ and incubation time for 2,4 and 6 days on the potential of hydrogen $(\mathrm{pH})$, total lactic acid bacteria , gram $+/$ - and the type of mold can be seen in Table 1 .
Table 1.

Variety Analysis of $\mathrm{pH}, \log$ total of BAL, Score of gram + / - Parameters and The Type of Mushroom on Liquid Extract Fermented Waste

Vegetable from Market with Difference of Glucose Level and Incubation Time

\begin{tabular}{lcccc}
\hline Variety Analysis & \multicolumn{4}{c}{ Parameters } \\
\cline { 2 - 5 } & $\mathrm{pH}$ & Log BAL & Gram $+/-$ & $\begin{array}{c}\text { Type of } \\
\text { mushroom }\end{array}$ \\
\hline $1^{\text {st }}$ Factor & $* * *$ & $* *$ & $\mathrm{~ns}$ & $\mathrm{~ns}$ \\
$2^{\text {nd }}$ Factor & $* *$ & $* * *$ & $\mathrm{~ns}$ & $\mathrm{~ns}$ \\
$1^{\text {st }} \times 2^{\text {nd }}$ Factor & $\mathrm{Ns}$ & $*$ & $\mathrm{~ns}$ & $\mathrm{~ns}$ \\
\hline
\end{tabular}

Significasi level : * $\mathrm{P}<0,05$; $^{* *} \mathrm{P}<0,01$ and ${ }^{* *} \mathrm{P}<0,001$

The mean inter-factor on parameters of $\mathrm{pH}, \log$ total lactic acid bacteria, gram $+/$ - score and the type of mushroom on liquid extract fermented waste vegetable from market with difference of glucose level and incubation period of time can be seen in Table 2 .

Table 2.

The Average of Inter-Factor for $\mathrm{pH}$ parameters on Solution Liquid Extract of Fermented Waste Vegetable from Market with Difference of Glucose Level and Incubation Time.

\begin{tabular}{|c|c|c|c|c|}
\hline $2^{2 \text { nd }}$ & 2 days & 4 days & 6 days & Average \\
\hline $\begin{array}{l}\text { Factor } \\
1^{\text {st }} \text { Factor }\end{array}$ & & & & \\
\hline Glucose $2 \%$ & 3.71 & 3.74 & 3.91 & $3.79 \mathrm{~b}$ \\
\hline Glucose $4 \%$ & 3.94 & 3.98 & 3.96 & $3.96^{\mathrm{a}}$ \\
\hline Glucose $6 \%$ & 3.81 & 3.93 & 4.03 & $3.92^{\mathrm{a}}$ \\
\hline Average & $3.82^{b}$ & $3.88^{\mathrm{ab}}$ & $3.96^{\mathrm{a}}$ & \\
\hline
\end{tabular}

The different super scripts in the same column and row shows significant difference $(\mathrm{P}<0,05)$.

The results of variety analysis shows that there are effect between glucose addition and incubation time treatment to $\mathrm{pH}$ and total lactat acid bacterial (BAL), but there is no interaction between addition of glucose and incubation time treatment for gram-positive (+) / gram negative (-) content and type of fungi on liquid solution of extract fermented waste vegetable from market. This means that the difference addition of glucose and incubation time treatment have reciprocity and mutual influence for $\mathrm{pH}$ and total lactic acid bacteria but not in gram $+/$ - and a type of fungus.

The addition of glucose is higher with the longer incubation time period give the result for higher $\mathrm{pH}$ value, the lowest $\mathrm{pH}$ value is the addition of glucose in level $2 \%$ with 2 days of incubation time treatment (Table 2). The decline $\mathrm{pH}$ value due to the microbes contained Lactobacillus Sp. and Saccharomyces Sp. on solution liquid extract of fermented waste vegetable from market whereas they have heterofermentatif and homofermentatif metabolism. Lactobacillus $S p$. and Saccharomyces $S p$. on solution liquid extract fermented waste vegetable from market can grow rapidly with glucose and inhibit other microorganisms that have lactic acid products. In line with the research that have been done by Frazier and Westhoff (1988) extract fermented waste vegetable from market has a $\mathrm{pH}$ around 3.4 to 3.8 . Glucose used as a source of energy that can be directly utilized by the microbes with the final result in the form of lactic acid on homofermentatif bacteria, while heterofermentatif produce lactic acid and $\mathrm{CO}_{2}$. Increasing the $\mathrm{pH}$ value in line with the length of storage, it is possible as a result of secondary metabolites like $\mathrm{H}_{2} \mathrm{O}$ and $\mathrm{CO}_{2}$ 
accumulates on solution liquid extract fermented waste vegetable from market into a weak acid $\left(\mathrm{HCO}_{3}\right)$, result in a rising $\mathrm{pH}$. The best time of incubation on this study was in 2 days. This study is better than Barrangou et al. (2002) with 2 days incubation declining down the $\mathrm{pH}$ from 6.5 to 4.2 with lactic acid bacteria population of $10^{8} \mathrm{cfu}$. Acidproducing microbes that grow in the liquid extract fermented waste vegetable from market possible to produce high acid with a low $\mathrm{pH}$ indicate as a good starter. The quality on the solution of liquid extract fermented waste vegetable from market showed that fermentation process of acid-producing microbial fermentation to produce lactic acid products running smoothly. A number of spoilage bacteria that live only at high $\mathrm{pH}$ are not able to grow due to not resistant to acid conditions. According to Desrosier (1988) and Daulay and Rahman (1992), until the 2 nd day of the fermentation dominated by the growth of Leuconostoc mesentroides produce acid from 0.7 to $1.0 \%$, and after then the population were declined. Population decline is due to the acid medium, unavailable nutrients and the bacteria static phase had passed. Lactic acid bacteria have contributed to lowering the $\mathrm{pH}$ rapidly thus inhibiting growth of unwanted microbes. Enzyme activity of the microbial heterofermentatif (Lactobacillus $S p$.) produces $\mathrm{CO}_{2}$ which makes anaerobic conditions and create ideal environmental conditions for the continuation of the species of lactic acid bacteria fermentation.

The combination treatment of $2 \%$ glucose and 2 days of incubation time obtained the highest amount of total lactic acid bacteria (Table 3 ).

Table 3.

The Interaction of Inter- Factors for Total BAL Parameters on Solution Liquid Extract fermented Waste Vegetable from Market with Difference of Glucose Level and Incubation Time.

\begin{tabular}{|c|c|c|c|c|}
\hline $\begin{array}{l}2^{\text {nd }} \text { Factor } \\
1^{\text {st }} \text { Factor }\end{array}$ & 2 days & 4 days & 6 days & Average \\
\hline Glucose $2 \%$ & $8.82^{\mathrm{a}}$ & $6.67^{\mathrm{ab}}$ & $6.67^{\mathrm{ab}}$ & $7.38^{\mathrm{a}}$ \\
\hline Glucose $4 \%$ & $8.01^{\mathrm{ab}}$ & $8.33^{\mathrm{ab}}$ & $2.50^{\mathrm{c}}$ & $6.28^{a}$ \\
\hline Glucose $6 \%$ & $5.67 \mathrm{bc}$ & $4.85^{\mathrm{bc}}$ & $2.61^{\mathrm{c}}$ & $4.38^{\mathrm{b}}$ \\
\hline Average & $7.50^{\mathrm{a}}$ & $6.62^{\mathrm{b}}$ & $3.92^{\mathrm{c}}$ & \\
\hline
\end{tabular}

The different super scripts in the same column and row shows significant difference $(\mathrm{P}<0,05)$.

This phenomenon is a portrait of the lactic acid bacteria in 2 days can grow well in the presence of $2 \%$ glucose. Lactic acid bacteria can survive because of the nutrients needed for growth available in liquid extract of fermented waste vegetable from market. Glucose in the liquid extract of fermented waste vegetable from market was used as an energy source and suspected adequate the nutritional needs for the growth of lactic acid bacteria. Widodo (2003) stated that the growth and survival of lactic acid bacteria (LAB) were influenced by several factors, as followed: the fermentable carbohydrates (glucose), $\mathrm{pH}$ conditions of about 4-5, the appropriate growth temperature and the interaction between BAL strains itself is very likely affect the composition of BAL in feedstuffs. Table 3 shows that the number of log BAL decreases with increasing curing time. This condition was due to lactic acid bacteria (LAB) had reached phase static (fixed) and further lactic acid bacteria population had declined due to death. The results showed a growth phase optimal lactic acid bacteria at 48 hours, after which the population was declined because of acid production inhibit the growth of microbes and reducing the nutrients contained in the media. According to Nurwantoro and Djariyah (1997) Microbial population began to die due to lack of nutrients in the media, energy reserve in the cell and also the possibility of acid produced by the microbes themselves.

The results of the analysis indicated that there were no significant effect between the treatments and the period time of incubation with addition of glucose to the content of gram-positive and gram-negative (Table 1). Microbes in the liquid extract of fermented waste vegetable from market were classified as gram-positive bacteria Lactobacillus sp. and which were tend not to harm. Lactobacillus $S p$. on the extract of fermented waste vegetable from market could grow rapidly with the salts and glucose content as well as able to produce acid, thereby inhibit the other microbes. Effective use of glucose by 2 days of curing time can reduce the pH from 6.5 to 4.2 (Barrangou et al., 2002). Plasmolosis was being the action mechanism of salts as selective media, because the salt has a high osmotic pressure. Supardi and Sukamto (1999) stated that the salt was hygroscopic thus it can absorb water from the microbial cells resulting water activity (aw) of these microbes is low. Salt can reduce the solubility of oxygen, so aerobic microbes can be prevented its growth. Total of salt are added to the study at $8 \%$ affect microbial populations, so that only specific microbes can grow main types of Lactobacillus Sp. Desrosier (1988) stated that the salt in food can pressing the growth of certain microbes through the limitation of available water, can dry and cause plasmolisis cytoplasm. Therefore, the salt can act as selectors needed to grow the organism in the fermentation. Soeparno (1994) stated that a number of bacteria growth was inhibite only by $2 \%$ salt content and can cause of death.

The results of variety analysis showed that the factor glucose, incubation time and the interactions did not give significant affect for the type of fungi. The kind of yeast obtained was Saccharomyces cerevisiae. This kind of yeast naturally contained in liquid extract of fermented waste vegetable from when glucose avalaible as a source for growing. Yeast is also able to survive at $\mathrm{pH} 1.5$ to 11 . Barrangou et al. (2002) said that the extract of fermented waste vegetable from market contained several species of bacteria such as Leuconostoc mesenteroides, Lactobacillus brevis, Lactobacillus plantarum, Pediococcus pentosaceus and Saccharomyces cerevisiea. Saccharomyces cerevisiea also used in animal feed as prebiotics and probiotics because it contains $\beta$-glucan immunostimulan and mannan oligosaccharides. Saccharomyces cerevisiea have special characteristics in the diet because of its ability to produce glutamic acid which able to increase the palatability of substrate fermentation media. Specific interaction between Saccharomyces cerevisiae and pathogenic bacteria such as Escherichia coli and Salmonella ilustrated that Saccharomyces as a binder of enterotoxigenic enterobacteria can be react on the surface of the intestine through the mannose-specific. Saccharomyces cerevisiae is possible to maintain the condition of the digestive tract when they live on the surface of cells of the small intestine 
(Brugier and Patte 1975). Rose (1987) stated that the ideal Saccharomyces cerevisiae yeast culture used for the production of the microbes intestinal can change, if the intestinal $\mathrm{pH}$ in control. According to Leeson and Summers (1996) Saccharomyces cerevisiae provided water supply to deliver oxygen, thus enhancing the growth of microbes in anaerobic conditions.

Based on the research of microbial characteristics on liquid extract of fermented waste vegetable from market with 2 days if incubation time and $2 \%$ glucose level were give a $\mathrm{pH}$ of $3.71, \log$ total lactic acid bacteria of 8.82 also Lactobacillus Sp. and Saccharomyces sp as predominant microbes. This result is the best and continued in subsequent research.

Table 4 shows the effect of treatment of toluene moisture, ash, crude protein, crude fat, crude fiber, nitrogen free extract material (NFE) and biomass. The results of variety analysis indicate that there were several treatments effect on the addition of liquid extract of the fermented waste vegetable from market for toluene moisture, ash, crude protein and crude fiber but for crude fat content, nitrogen free extract materials (NFE) and biomass were not.

The moisture content on the material reflected the moisture content after fermentation. The higher use of level extract liquid of fermented waste vegetable from market makes the decrease of average amount for water content of toluene. The decrease occurred because the fermentation process takes place in an aerobic facultative with microbial extracts contained in the liquid waste vegetable market genus Lactobacillus and Saccharomyces

Tabel 4.

The Average of Moisture Content, Ash Content, Crude Protein, Crude Fat, Crude Fiber, NFE and Biomass of Fermented Rice Bran with Various Liquid Extract of Fermeneted waste Vegetable from Market.

\begin{tabular}{|c|c|c|c|c|}
\hline \multirow{2}{*}{ Parameter } & \multicolumn{4}{|c|}{ Treatments } \\
\hline & $\mathrm{T}_{0}$ & $\mathrm{~T}_{20}$ & $\mathrm{~T}_{40}$ & $\mathrm{~T}_{60}$ \\
\hline & \multicolumn{4}{|c|}{ - } \\
\hline Moisture & $66,97^{a}$ & $65,23^{b}$ & $65,24^{b}$ & $62,77^{c}$ \\
\hline Ash & $11,42^{\mathrm{d}}$ & $12,19^{\mathrm{c}}$ & $13,36^{b}$ & $14,24^{\mathrm{a}}$ \\
\hline Crude Protein & $15,52^{\mathrm{a}}$ & $14,88^{b}$ & $14,93^{\mathrm{b}}$ & $14,34^{c}$ \\
\hline Crude Fat & 7,43 & 7,76 & 7,61 & 7,57 \\
\hline Crude Fiber & $12,66^{\mathrm{a}}$ & $12,31^{\mathrm{a}}$ & $12,39^{a}$ & $9,54^{b}$ \\
\hline NFE & 52,94 & 52,84 & 51,69 & 54,30 \\
\hline Biomassa & 0,04 & 0,02 & 0,07 & 0,05 \\
\hline
\end{tabular}

The different superscrip in the same column and row shows significant difference $(\mathrm{P}<0,05)$.

\section{Value Retention of Nutrition and Metabolic Energy.}

Table 5 shows the effect of treatment on nitrogen, calcium and phosphorus retention, apparent metabolizable energy (AME) and true metabolizable energy (TME). Apparent metabolizable energy (AME) of rice bran values and rice bran fermentation was significantly different, but TME not. This phenomenon is due to the composition of carbohydrate fermented rice bran was broken down by Saccharomyces sp. a simple monosaccharide that is easily absorbed by the body of cattle. fermentation thus the by products of fermentation in the vapor form of $\mathrm{H}_{2} \mathrm{O}$ and $\mathrm{CO}_{2}$. Fardiaz (1993) stated that Saccharomyces produces gas and other volatile compounds characterized by the smell of fermentation products that dealing with the texture of fermented rice bran. Changes in fermented rice bran arisen acid and strong aroma. The proven given in this study that fermentation process was runs smoothly and produces secondary metabolites such as acids and $\mathrm{CO}_{2}$. The fermentation process has the objective to produce a product that has a nutrient content, texture, better biological avalability, and also it can reduce the antinutritional substances (Winarno, 1984).

Changes in the proximate in fermented rice bran of the most influential are the change in the levels of crude protein and crude fiber. Ash content, crude fat, NFE and biomass are the result of the qualitative changes caused by microbial role. The role of microbes in liquid extract of fermented vegetable market waste can convert nutritional components related to the ability of microbes to convert protein and crude fiber as a source of protein and energy.

The best results of the study for the effectiveness of the liquid extract of fermented waste vegetable from market as a starter for the fermentation of rice bran in an effort to improve the quality and utility as poultry feed ingredients, namely the addition of treatment of waste liquid extract fermented vegetable market on the basis of $40 \%$ of the proteins that are relatively similar to unfermented but rice bran content lower rough fibers and produce the highest biomass (Table 4).

Tabel 5.

The Average of Nitrogen Retention Value, Retention of Calcium, Phosphorus Retention and Metabolic Energy Rice Bran Fermented In Post-hatching Broiler Chickens

\begin{tabular}{lcll}
\multicolumn{3}{c}{ Post-hatching Broiler Chickens } \\
\hline Treatment & Fermented Rice Bran & $\begin{array}{l}\text { Unfermented } \\
\text { Bran }\end{array}$ & Rice \\
\hline TME & $3832,76^{\mathrm{a}}$ & $3963,88^{\mathrm{a}}$ & \\
AME & $3165,50^{\mathrm{b}}$ & $3510,56^{\mathrm{a}}$ & \\
Retensi N & $23,84^{\mathrm{b}}$ & $35,09^{\mathrm{a}}$ & \\
Retensi Ca & $7,51^{\mathrm{b}}$ & $72,86^{\mathrm{a}}$ & \\
Retensi P & $8,74^{\mathrm{b}}$ & $40,10^{\mathrm{a}}$ & \\
\hline
\end{tabular}

The different superscrip in the same column and row shows significant difference $(\mathrm{P}<0,05)$.

The fermentation process has the objective to produce food that has nutritional content, texture, better biological availibility, in addition, to reduce anti-nutritional substances (Winarno, 1984). Tawwab et al. (2008) stated that the granting of Saccharomyces cerevisiae to improve the digestibility of protein and fiber. The statement is consistent with the results of the study Kumprechtova et al. (2000) reported that supplementation with Saccaromyces can improve the productivity of broiler chickens, although the low protein content of the ration. True metabolizable energy (TME) on rice bran and rice bran fermentation fermentation without no different since there is a gross energy content of rice bran and rice bran on the fermentation is not much different. Gross energy content of rice bran without fermentation is about $3965.78 \mathrm{kcal} / \mathrm{kg}$, while the fermented rice bran of 4065.73. The $100 \mathrm{kcal}$ difference gross energy were not affected to the metabolic activity of broiler chickens 
(Lopez and Leeson, 2007). Biological values of fermented rice bran for broiler chickens after hatching as indicated by retention nitrogen value, calcium, phosphorus and metabolic energy proves that the availibility fermentation rice bran is higher than without fermented rice bran.

\section{CONCLUSION}

Utilities and benefit values of rice bran were increased by the fermentation using $40 \%$ liquid extract of fermented waste vegetable from market which in control by glucose concentration of $2 \%$ glucose with 2 days incubation period of time. The increasing values were seen from nitrogen, calcium and phosphorus retention also from apparent metabolizable energy (AME).

\section{REFERENCES}

[1] Atlas, R. M. 2005. Media for Environmental Microbiology. CRC Press

[2] Central Statistic Agency (BPS). 2005. Central Statistic Agency District of Semarang in the Year of 2005. Central Statistic Agency, Semarang Dictrict.

[3] Barrangou, R., S. Yon, F. Breidt, H. Fleming and T. Klaenhammer. 2002. Indentification and Characterization of Leuconostoc Fallax Strains Isolated from an industrial Ekstrak limbah pasar sayur fermentasi fermentation. Appl. Environ. Microbiol. Am. Soc. Microbiol. 6: 2877-2884.
[4] Brugier, S and F. Patte. 1975. Antagonisus zwichen saccharomyces cerevisiae und verschiedenen bakterien in vitro. Versuch. Le Me'd de Paris 4:3-8.

[5] Edo, T., M. Nakano., S. Shimizu., M. Fukushima and S. Miyoshi. 1999. Effect of probiotic on the lipid metabolism of cocks fed on cholesterol-enriched diet. Biosci. Biotechnol. Biochem. 63 (9): 15691575. Fardiaz, S. 1993. Food Microorganisms Analysis. 1st edition. Raja Grafindo Persada, Jakarta.

[6] Frazier, W. dan D. C. Westhoff. 1988. Food Microbiology. 4th Ed. McGraw-Hill Book Company, Singapore.

[7] Hadisuwarno, R. S. 1990. Basic Microbilogy in the Laboratory Procedures and Practices. PT. Gramedia, Jakarta.

[8] Kumprechtova, D., P. Zobac and I. Kumprecht. 2000. The effect of Saccharomyces cerevisiae Sc 47 on chicken broiler performance and nitrogen output. Czech. J. Anim. Sci. 44(5): 169-177.

[9] Leeson, S. and J. D. Summer. 1996. Commercial Poultry Nutrition. $2^{\text {nd }}$ Ed. University Books. University of Guelph. Guelph, Ontario.

[10] Lopez, G and S. Leeson. 2007. Relevance of Nitrogen Correction for Assessment of Metabolizable Energy with Broilers to Forty-Nine Days of Age. Poultry. Sci. 86:1696-1704.

[11] Nurwantoro dan A. Djarijah. 1997. Food Microbiology. Kanisius, Yogyakarta

[12] Reddy, N. R. and S. K. Sathe. 2002. Food Phytates. CRC Press LLC

[13] Rose, A.H. 1987. Biotechnology in The Feed Industry. In: Alltech's $3^{\text {rd }}$ Annual Symposium Biotechnology in the Feed Industry. Lexington

[14] Tawwab, M. A., M. Azza., A. Rahman and N. E. M. Ismael. 2008. Evaluation of Commercial Live Bakers Yeast, Saccharomyces cerevisiae As A Growth and Immunity Promoter for Fry Nile Tilapia, oreochromis niloticus (L.) Challenged in Situ with aeromonas hydrophila. Aquacult. $280: 185-189$ 